Türk Turizm Araştırmalari Dergisi
2021, 5(1): 593-609.
ARSOSTIRMA MAKALESI $2587-0890$ Dergi web sayfasi: $\underline{\text { https://www.tutad.org }}$

\title{
Kriz Döneminde Otel İşletmeciliği Alanında Pazarlama, Finansman ve Maliyet Odaklı Eylemler
}

Dr. Öğr. Üyesi Taner SIĞINDI, Muğla Sıtkı Koçman Üniversitesi, İktisadi ve İdari Bilimler Fakültesi, Muğla, e-posta: tanersigindi@mu.edu.tr ORCID: https://orcid.org/0000-0002-9048-7718

Dr. Öğr. Üyesi H. Cem SAYIN, Anadolu Üniversitesi, İşletme Fakültesi, Eskişehir, e-posta: hcsayin@anadolu.edu.tr ORCID: https://orcid.org/0000-0003-3487-805X

Öz

Bu çalışmada, karar vericilerin otel işletmeciliği alanında yaşanan krizlerde alınması gereken pazarlama, finansman ve maliyet odaklı önlemler konusundaki değerlendirmeleri incelenmiştir. Bunun yanısıra, söz konusu önlemlerin ne derece faydalı oldukları konusunda karar vericilerin değerlendirmeleri belirlenmiştir. Bu bağlamda, Muğla ilinde faaliyet gösteren otel işletmelerinde iki aşamalı bir araştırma gerçekleştirilmiştir. Derinlemesine görüşme yöntemi ile elde edilen veriler betimleyici analiz kullanılarak analiz edilmiştir. Krizin hissedilmeye başlandığı dönemde yani araştırmanın ilk aşamasında, katılımcılar devletin ülke tanıtımına ekstra kaynak ayırmanın yanında vergi indirimleri ve borç yapılandırma gibi çözümler üretmesi gerektiğini savunmuşlardır. Bunun yanı sıra firma bünyesinde ise personel sayısının azaltılması, personel ücretlerinin düşürülmesi, sunulan mal ve hizmetlerde sınırlamaya gidilmesi, pazarlama iletişimi bütçesinin azaltılması, uygulanan fiyatlarda indirime gidilmesi gibi stratejiler üzerine odaklandıkları görülmüştür. Krizin etkilerinin azalmaya başladığı dönemde gerçekleştirilen araştırmanın ikinci safhasında ise katılımclar devlet uygulamalarının çözüm üretmekte beklenen düzeyde gerçekleşmediğini düşünmektedir. Katılımcılar özellikle iş alanlarında KDV indirimine gidilmemesi, ülkenin tanıtımı için pazarlama iletişimi stratejilerinde gerekli değişikliklerin yapılmaması gibi durumlardan yakınmışlardır. Personel harcamalarındaki indirimin işe yaradığını savunan katılımcılar çoğunlukta iken, pazarlama iletişimi faaliyetlerini azaltmanın düşen talebi daha da kötü yönde etkilediği sonucuna ulaşılmıştır.

*Bu çalışma, 5-8 Eylül 2018 tarihinde Podgorica, Montenegro'da gerçekleştirilen 'International Symposium on Business and Economics'de sunulan "A Study on Marketing and Cost Oriented Strategies During the Crisis in Accommodation Industry" adlı bildiri temel alınarak hazırlanmıştır.

Anahtar Kelimeler: Kriz, Konaklama, Pazarlama, Maliyet Azaltımı, Finansman.

Makale Gönderme Tarihi: 23.10.2020

Makale Kabul Tarihi: 05.03.2021

\section{Önerilen Atıf:}

Sığındı, T. ve Sayın, H. C. (2021). Kriz Döneminde Otel İşletmeciliği Alanında Pazarlama, Finansman ve Maliyet Odaklı Eylemler, Türk Turizm Araştırmaları Dergisi, 5(1): 593-609.

(C) 2021 Türk Turizm Araştırmaları Dergisi. 


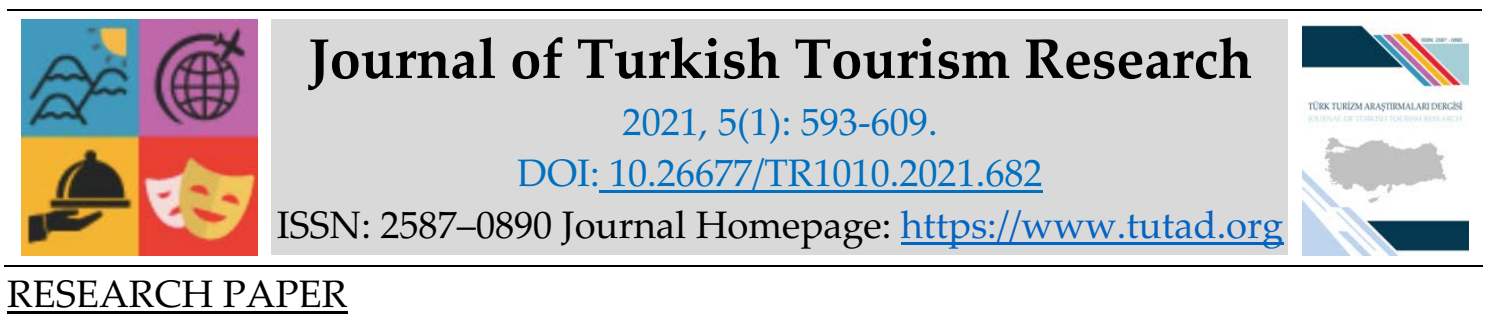

\title{
Marketing, Financing and Cost Oriented Actions During the Crisis in the Hotel Industry
}

Assistant Prof. Dr. Taner SIĞINDI, Muğla Sıtkı Koçman University, Faculty of Economics and Administrative Sciences, Muğla, e-mail: tanersigindi@mu.edu.tr

ORCID: https://orcid.org/0000-0002-9048-7718

Assistant Prof. Dr. H. Cem SAYIN, Anadolu University, Faculty of Management, Eskişehir, email: hcsayin@anadolu.edu.tr

ORCID: https://orcid.org/0000-0003-3487-805X

\begin{abstract}
In this study, the evaluations of decision makers on marketing, financing and cost-oriented measures that should be taken in the crisis in the hotel industry were examined. In addition, the evaluations of decision makers regarding the effectiveness of these measures were determined. In this context, a two-phased research has been conducted in the hotels operating in Mugla, Turkey. The data were collected by in-depth interviews and descriptive analysis was used to analyze it. In the first phase of the research, when the crisis was begun to feel, participants assert that the government should provide some actions such as tax reductions and debt restructuring in addition to allocating extra resources to the country promotion. Besides, respondents focus on strategies such as destaffing, reducing personnel wages, limiting the goods and services offered, reducing the marketing communication budget, and to lower the prices. In the second phase, when the effects of crisis are almost over, the respondents think that government practices did not effective enough to get the expected solutions. Respondents also complain about the lack of improvement in the marketing communication strategies of the country and not reducing the VAT rates in the industry. The majority of participants suggest that the limiting the activities of marketing communication affected the demand negatively while the reduction in personnel expenses was beneficial.
\end{abstract}

Keywords: Crisis, Accommodation, Marketing, Cost Reduction, Financing.

Received: 23.10 .2020

Accepted: 05.03.2021

\section{Suggested Citation:}

Sığındı, T. and Sayın, H. C. (2021). Marketing, Financing and Cost Oriented Actions During the Crisis in the Hotel Industry, Journal of Turkish Tourism Research, 5(1): 593-609.

(C) 2021 Türk Turizm Araştırmaları Dergisi. 


\section{Gíriş}

Turizm, ekonomik açıdan önemli sektörlerden biri olup oldukça hassas ve kırılgan bir yapıya sahiptir. Bu durumun başlıca nedenlerinden biri turizm sektörünün döviz kuru, politik koşullar, çevre ve hava koşulları gibi dışsal faktörlerden etkilenmesidir (Pforr, 2009; Ritchie, Crotts, Zehrer ve Volsky, 2013). Turizm sektörü, kontrol edilemeyecek şekilde dışsal faktörlerden etkilenen açık bir sistem olarak tanımlanmaktadır. Bu nedenle böyle karmaşık bir sosyal bilim alanında statik öneriler ile kriz yönetimini tarif etmek mümkün görünmemektedir. Krizler dinamik bir yapıya sahip olduğundan, krizle mücadele yöntemlerinin de bu düzensiz çevreye uygun şekilde düzenlenmiş olması gerekmektedir (Ritchie vd., 2013; Scott, Laws ve Prideaux, 2007).

Her bir krizin kendine özgü yapısı olmakla birlikte krizlerin etkileri ve bu etkilerle mücadele yöntemleri de işletmelerin yapılarına ve bulundukları çevreye bağlıdır (Stafford, Yu ve Armoo, 2002). Turizm sektöründeki farklı faaliyet alanlarında karar vericiler krizle mücadele etmek için öncelikle içinde bulundukları durumu doğru bir şekilde analiz etmeli, daha sonra karşılaştıkları krize özgü önlemleri uygulamaya koymalıdırlar (Cushnahan, 2004). Bunun için karar vericilerin gerekli hamleleri doğru değerlendirmeleri ve isabetli kararlar almaları gerekmektedir. Yazında krizle mücadele sürecinde farklı paydaşların sorumluluklarından bahsedilmektedir. Bu paydaşların başında işletmeler gelmektedir ve kullandıkları yöntemlere odaklanan çok sayıda çalışma (bknz. Ritchie ve Jiang, 2019) bulunmaktadır. Bu yöntemler içinde pazarlama ve maliyet odaklı eylemler önemli bir yer tutmaktadır (Cushnahan, 2004; del Mar Alonso-Almeida ve Bremser, 2013). Kriz dönemlerinde etkili olan bir diğer önemli paydaş devlettir. Devletler krizlerin etkisini azaltmak için çeşitli araçlar ile işletmelere yardımcı olmaya çalışırlar (del Mar Alonso-Almeida ve Bremser, 2013; Sawalha, Jraisat ve Al-Qudah, 2013; Sigindi, 2018).

Krizlerin turizm sektörüne etkilerini inceleyen ve bütünsel bir yaklaşım sergileyen sınırlı sayıda çalışma bulunmaktadır (Ritchie vd., 2013). Diğer yandan farklı paydaşların kriz dönemlerinde neler yapılması gerektiği konusundaki görüşlerine yeterince odaklanılmadığı söylenebilir. Özellikle krizler ile nasıl mücadele edileceği konusunda karar vericilerin neler düşündüklerinin bilinmesinin, doğru eylemlerin tespit edilmesi ve uygulanması konusunda faydalı olacağı düşünülmektedir. Ayrıca karar vericilerin, yapılacak eylemler konusunda hangi paydaşı ne düzeyde sorumlu gördüklerinin anlaşılması, krizle mücadelede eşgüdümü kolaylaştıracaktır.

Turizm sektörü ulusal gelir içindeki payının büyüklüğü, cari işlemler dengesi üzerindeki güçlü etkisi, yarattığı geniş istihdam olanakları, farklı sektörlerle olan doğrudan veya dolaylı ilişkisi ve uluslararası pazarda ülkenin tanınırlığının artmasında sahip olduğu rol gibi unsurlar nedeniyle Türkiye ekonomisinde oldukça önemli bir yere sahiptir. Büyük bir ekonomik potansiyele sahip olan turizm sektörü, buna karşın çevresel ve içsel faktörlerden kolaylıkla etkilenebilen, hassas bir yapıdadır (Kaya, 2017). Dolayısıyla, siyasi ve ekonomik krizler, doğal afetler, savaşlar, terör olayları, hükümet politikaları ve diğer etkenler turizm sektöründe faaliyet gösteren işletmelerin performansını olumsuz etkileyebilmektedir. Gerek ülke ekonomisinde sahip olduğu önemli yer gerekse krizler karşısında kırılgan bir yapıda olması turizm sektöründeki işletmelerin krizlerle başa çıkma stratejilerine yönelik araştırma ve çalışmaları zorunlu kılmaktadır. Bu noktadan hareketle ve otel işletmelerinin turizm sektöründe konaklama alanında en önemli alt sistemlerden biri olması dolayısıyla, bu çalışmada otel işletmeciliği alanında yaşanan bir krizin başlangıç sürecinde ve sonrasında pazarlama, finansman ve maliyet odaklı olarak alınan önlemler ve kararlaştırılan eylem planlarının yanında bu planların ve önlemlerin ne derece faydalı olduklarına ilişkin işletme ortaklarının ve yöneticilerin değerlendirmeleri incelenmiştir. 


\section{KAVRAMSAL ÇERÇEVE}

Bu kısımda ilk olarak kriz kavramı ve farklı kriz türleri hakkında bilgiler verilmektedir. Daha sonra, çalışmaya konu olan 2016 krizinin nedenleri ve etkileri açıklanmakta, turizm sektöründe krizlerle başa çıkabilmek için yapılan maliyet, finansman ve pazarlama odaklı stratejiler aktarılmaktadır.

\section{Kriz Kavramı ve Krizlerin Sınıflandırılması}

Kriz, geniş bir bakış açısı ile birey veya örgüt tarafından karşılaşılan ve rutin yöntemlerle çözülemeyen her türlü durum olarak tanımlanmıştır (Booth, 1993). Bu tanıma göre kriz, bir sosyoekonomik sistemin (örgütün) veya bireyin varlığını ve yakın çevresini tehdit eden bir tür aşırı uyumsuzluk hali olarak ifade edilmektedir. Bir başka tanıma göre ise kriz, yüksek düzeyde belirsizlikler ve öncelikli hedeflere yönelik önemli bir tehdit oluşturan beklenmedik, rutin olmayan belirli bir olay veya olaylar dizisidir (Seeger, Sellnow ve Ulmer, 2003).

İşletmecilik açısından kriz bir firmanın uzun vadedeki büyümesini, kârlılı̆̆ını hatta varlığını tehdit eden herhangi bir olay olarak tanımlanmaktadır. İşletmelerin karşılaştığı krizler genel bir bakış açısıyla içsel ve dışsal olmak üzere iki ayrı etmenden kaynaklanmaktadır. Dışsal etmenler arasında ürün veya hizmet talebinde dalgalanma, kredi politikası, müşteri firmalarının ödeme zorlukları, ekonomik döngüler, siyasal belirsizlik, kazalar, kişisel kayıplar, hükümet düzenlemeleri, enflasyon, uluslararası rekabet ve doğal çevre yer almaktadır. İçsel etmenler arasında yanlış politikalar, düşük kaliteli ürünler, kaynakların yanlış kullanımı, yönetim hataları, yetersiz bir güvenlik anlayışı ve çarpık bir örgüt kültürü sayılabilir (Iivari, 2012).

Bir krizin dışsal etmenleri, krizin gerçekleşmesi için elverişli koşullar yaratan olaylardır. Bu etmenler fiziksel veya sosyal çevreden kaynaklanabilir. Örneğin doğal afetler, petrol tankerinin batması gibi felaketler fiziksel çevrede gerçekleşirken; grevlerin işleri aksatması, terör saldırıları gibi etmenler sosyal çevreye özgüdür. İçsel etmenler ise kuruluşa özgü çeşitli hataları içermektedir. İçsel çevrede işletmelerin çevreyi kirleten faaliyetleri, müşterilerine bozuk yiyecek sunması, finans yöneticilerinin kural ihlâlleri gibi durumlar buna örnek olarak verilebilir (Lerbinger, 1997; Stafford vd., 2002).

Krizler farklı biçimlerde sınıflandırılmaktadır. Karşı karşıya kalınabilecek kriz türlerini bilmek, her biri için uygun mücadele stratejileri geliştirilebilmesi açısından önem taşımaktadır. Meyers ve Holusha (1986) krizleri; piyasadaki ani dalgalanmalar, endüstrinin millileştirilmesi veya özelleştirilmesi ve para arzının daralması bağlamında ele almışlardır. Diğer taraftan Lerbinger (1986) krizleri teknolojik, cepheleşen, kötü niyete dayanan ve yönetim hatasına ilişkin olmak üzere dört gruba ayırmıştır. Smith ve Millar (2002) ise krizleri; ani olanlar, içten içe gelişenler, algısal olanlar ve olağandışı krizler olmak üzere dört başlık altında sınıflandırmışlardır.

Krizler ayrıca ekonomik, siyasal, sosyal, örgütsel, teknolojik ve ekolojik krizler olarak da sınıflandırılabilir (Iivari, 2012). Kriz türlerine ilişkin sınıflandırmalar farklı olsa da işletmeler açısından önemli olan krizlerin ekonomik durumu olumsuz etkileme potansiyelidir. Krizler genellikle talep ve gelirlerde azalma, maliyetlerde artıs, rutin operasyonlarda aksama, karar alma ve iletişim faaliyetlerinde başarısızlıklar, personel işten çıkarmaları, yatırımların iptal edilmesi, stresli yaşam ve çalışma ortamları ile kuruluşların kapanması gibi olumsuz sonuçlara sahiptir (Kash ve Darling 1998).

Farklı alanlar ve sektörler farklı kriz türleri ile karşı karşıya kalmaktadır. Bununla birlikte, bütün kriz durumlarında genellikle üç ana unsurun ortak olduğu görülmektedir. Söz konusu unsurları şöyle sıralayabiliriz (Hwang ve Lichtenthal, 1999): 
- $\quad$ Örgüte yönelik oldukça büyük bir tehdit söz konusudur (tehdit unsuru).

- $\quad$ Öngörülemeyen bir olay şeklinde gerçekleşir (sürpriz unsuru).

- $\quad$ Tepki verme aralığı çok dardır (zaman baskısı unsuru).

Kriz dönemlerinde, aniden gelişen beklenmedik olaylar örgütlerin sorun yaşamasına sebep olarak normal faaliyetlerini aksatmaktadır. Örgütlerin mevcut yapısı ve halihazırdaki süreçleri kriz dönemlerinde ortaya çıkan problemlere çözüm üretme konusunda yetersiz kalmaktadır. Dolayısıyla krizin üstesinden gelebilmek için, en kısa sürede örgütte gerekli değişikliklerin yapılması ve süreçlerin yenilenmesi gerekmektedir. Başka bir ifadeyle, krizler örgütleri hızlı bir değişime zorlamaktadır.

Bu çalışmada incelenen dönemdeki koşullar bir siyasi kriz niteliği taşımaktadır. Siyasi krizi, devletler ya da çeşitli güç odakları arasında 'çözülmesi mümkün ancak savaşa dönüşmesi de olası uyuşmazlıklar' olarak tanımlamak mümkündür. İzleyen kısımda, 2016 yılında Türkiye'de yaşanan siyasi krizin turizm sektörüne etkileri açılanmaktadır.

\section{Türkiye'de 2016 Yılında Yaşanan Siyasal Kriz ve Turizm Sektörüne Yansıması}

Ekonomik, siyasal ve çevresel etmenlerin yarattı̆̆ krizler otel işletmelerini farklı şekillerde olumsuz anlamda etkilemektedir. Turist sayısında düşüş, maliyetlerin artması, ticari ilişkilerin bozulması, finansman sıkıntısı ve işletmenin sürekliliğini tehdit edebilecek çok sayıda olumsuzluk ortaya çıkabilmektedir (Israeli, Mohsin ve Kumar, 2011; Kim, Chun ve Lee, 2005; Okumuş, Altınay ve Araslı, 2005). Bu sorunların üstesinden gelebilmek için öncelikle krizin nedenlerinin, boyutlarının, etkilerinin ve yönünün analiz edilmesi gerekmektedir. Dolayısıyla bu kısımda, 2016 yılında yaşanan ve Türkiye turizmi açısından bir kriz niteliği taşıyan olumsuzlukların nedenleri ve etkileri ele alınmaktadır.

Dünya genelinde 2014 yılı itibariyle petrol fiyatlarında yaşanan düşüş, vergi gelirlerinin büyük bölümünü petrol ve petrol ürünlerinden elde eden ülkelerin satın alma gücü paritelerinde zayıflamaya yol açmıştır. Özellikle vergi gelirlerinin \%50,2'sini petrol ve doğalgaz satışlarından elde eden Rusya, bu durumdan en çok etkilenen ülke olmuştur. Dünya petrol fiyatlarının sürekli gerilemesi ile yaşanan ekonomik sorunlar, Rus Rublesinin yabancı para birimleri karşısında hızla değer kaybetmesine ve finansal istikrarın bozulmasına neden olmuştur. Bu durum her ne kadar Rusya'dan Türkiye'ye olan turizm talebini olumsuz etkilese de, diğer ülkelere kıyasla bu etki sınırlı kalmıştır. Ancak, Türkiye'nin 2015 yılının ikinci yarısında ve 2016 yılında yaşamış olduğu olumsuz gelişmelerden dolayı turizm sektörü şiddetli bir krizin etkisine girmiştir. Rusya'ya ait savaş uçağının 24 Kasım 2015 tarihinde sınır ihlali nedeniyle Türk Silahlı Kuvvetleri tarafından düşürülmesi, Suriye'de devam etmekte olan savaş ve Türkiye'de meydana gelen terör olayları potansiyel turistlerin Türkiye'ye gelme kararlarını olumsuz etkilemiştir (Dalgıç ve Birdir, 2017).

Rusya Federasyonu'na ait savaş uçağının düşürülmesinin ardından iki ülke arasında yaşanan siyasi gerginlik sonucu, Rusya'nın Türkiye'ye yönelik tur satışlarını ve tarifesiz (charter) uçuşlarını yasaklaması ile Türkiye turizm sektörü zor durumda kalmıştır. Rusya'nın yıllık ortalama 4,5 milyon turist ile Türkiye'ye yönelen turizm talebinin \%12'sini oluşturan bir pazar konumunda olması, yaşanan olumsuzlukların boyutunu artırmıştır. 2016 yılında Rus turist sayısında \%76 oranında düşüş kaydedilmiştir (Kaya, 2017).

Diğer yandan 15 Temmuz 2016 tarihinde yaşanan darbe girişimi de Türkiye'nin içinde bulunduğu siyasi, ekonomik ve toplumsal yapıyı derinden etkilemiştir (Davras ve Aktel, 2018). Suriye'de yaşanan savaş, Rusya uçağının düşürülmesi, ülke genelinde yaşanan terör saldırıları, 15 Temmuz darbe girişimi ve sonrasında hayata geçirilen Olağanüstü Hal (OHAL) uygulamaları 
Türkiye turizminde ciddi kayıplara yol açmıştır. 2016'da gelen turist sayısı bir önceki yıla göre yüzde 30'luk düşüşle 41 milyon kişiden 31 milyon kişiye gerilemiştir. Turizm gelirleri de buna paralel şekilde yüzde 42 düşerek 31 milyar dolardan 22 milyar dolara kadar inmiştir (www.tursab.org.tr).

\section{Krizlerle Mücadele Etmek İçin Turizm Sektöründe Gerçekleştirilen Pazarlama, Finansman ve Maliyet Odaklı Eylemler}

Turizm sektörü doğa olaylarının yanı sıra terörizm, siyasi istikrarsızlık, savaş, siyasi çatışmalar, ekonomideki dalgalanmalar gibi insan kaynaklı krizler karşısında da oldukça kırılgan bir yapıdadır. Turizm sektöründe krizin gerçekleşme şekli nasıl olursa olsun, ayrıntılı eylem planlarına sahip işletmelerin krizleri en az zararla atlatarak hayatta kalma olasılığı yüksektir. Burada dikkat edilmesi gereken nokta, gerçekleşen krizin derinlemesine analiz edilmesi ve ona uygun stratejiler geliştirilmesi gerektiğidir. Çalışmanın bu kısmında, turizm sektöründe farklı kriz türlerine karşı işletmeler ve devlet tarafından gerçekleştirilen pazarlama, finansman ve maliyet odaklı eylem planlarına yer verilmektedir.

Terörizm kaynaklı krizlere yönelik olarak Sönmez, Apostolopoulos ve Tarlow (1999) ülkelerin içinde bulundukları koşullara göre farklı stratejiler uyguladıklarını ifade etmişlerdir. Örneğin Mısır, 90'lı yıllarda terörizmin turizm sektöründe yol açtığı krizle başa çıkabilmek için güvenlik önlemlerinin artırılarak, agresif pazarlama çabalarına ağırlık verilmesi stratejisini uygulamıştır. Mısır Turizm Bakanlığı, mevcut pazarlama stratejilerini gözden geçirerek yeni bir hedefler seti oluşturmuş ve bu kapsamda iletişim faaliyetlerini büyük ölçüde artırmıştır. Meksika, yine 1990'lı yıllarda Chiapas eyaletinde yaşanan çatışmaların bozduğu güven ortamını yeniden tesis etmek ve bölgede turizmi canlandırmak adına iş dünyası temsilcilerine 1 milyon davet mektubu göndermiştir. Mektupta şirketlere, toplantı ve kongrelerini Chiapas bölgesindeki otellerde gerçekleştirmeleri durumunda kendilerine vergi muafiyeti sağlanacağı ifade edilmiş, bunun yanı sıra otel fiyatlarında büyük indirimler sunulmuştur. Kuzey İrlanda ise, terör olaylarının yarattığı olumsuz etkiyi ortadan kaldırmak adına, turistik ziyaretleri artırmaya yönelik stratejiler geliştirmiştir. Yoğun tutundurma faaliyetleriyle desteklenen bu stratejiler arasında yeni turizm ürünleri geliştirilmesi, yeni cazibe merkezleri oluşturulması gibi çabalar yer almaktadır.

11 Eylül 2001 terörist saldırılarından sonra Washington D.C. nin krizle nasıl mücadele ettiğini Stafford ve diğg. (2002) incelemiştir. Kentin hızla düşen turizm girdilerini artırmak için öncelikle devletle sıkı işbirliği yapılarak tüm paydaşlar sürece dahil edilmeye çalışılmıştır. Ayrıca kent için yeni bir pazarlama programı oluşturmak üzere özel bir fon oluşturulmuştur. Acil tedbirler alındıktan sonra, özellikle uzun vadeli başarıyı hedefleyen yeni bir pazarlama programı oluşturulmaya çalışılmıştır. Bu program kapsamında kenti cazip kılacak yeni özellikler bulunarak tüketicilere tanıtılması hedeflenmiştir.

Konaklama endüstrisinde krizle mücadele stratejilerini ortaya koydukları çalışmalarında Bahar, Kaya ve Keklik (2011), küresel finans piyasalarında 2008 yılında ortaya çıan ve turizm sektörünü derinden etkileyen ekonomik kriz karşısında farklı ülkelerin uyguladıkları stratejileri şu şekilde sıralamışlardır;

- Fransa: Yiyecek-içecek endüstrisinde uygulanan KDV oranı azaltılmışır.

- İspanya: Turizm işletmelerinin alt ve üst yapı yenilemeleri için 1 milyar avroluk destek paketi hazırlanmıştır.

- İtalya: Sezon dışı fiyat indirimleri uygulanarak düşük gelir grubu pazara çekilmeye çalışılmıştır. 
- Yunanistan: Ülke tanıtım bütçesi \%50 oranında artırılmıştır. Turistlere yönelik olarak vize kolaylığı ve vergi indirimleri uygulanmıştır.

- Portekiz: Tanıtım kampanyaları yoğunlaştırılmış, sektörde kullanılmak üzere 500 milyon avroluk bir destek paketi uygulamaya konulmuştur.

- Avusturya: İşletmelere kredi sübvansiyonları sağlanması, banka garantisinin artırılması, yeni yatırımlara hibeler verilmesi, zor durumdaki işletmelere devlet destekli borçlar verilmesi gibi uygulamaları içeren bir destek paketi açıklanmıştır.

- Hollanda: Hazırlanan 6 milyar dolarlık destek paketi dahilinde havaalanı kalkış vergileri kaldırılmıştır.

- Hong Kong: Çok sayıda ülkeye yönelik vize uygulamasına son verilmiş, konaklama vergisi ve bazı içeceklerden alınan gümrük vergisi kaldırılmıs, daha yakın destinasyonları ve yeni ürünleri hedefleyen bir pazarlama stratejisi geliştirilmiştir.

del Mar Alonso-Almeida ve Bremser (2013), tüketicilerin gelirlerinin azaldığı bir dönemde İspanya' daki konaklama sektöründeki firmaların yüksek kalite, marka imajı ve tüketici sadakati odaklı eylemler ile krizle en iyi şekilde mücadele etmeleri gerektiği sonucuna ulaşmışlardır. Bunun yanında maliyet azaltıcı eylemler işletmelerin kriz döneminde kötü performans göstermelerine yol açmıştır.

Görüldügü üzere, kriz dönemlerinde uygulanan krizle mücadele stratejileri gerek krizin türüne gerekse ülkelere özgü koşullara göre farklılıklar göstermekle birlikte, turizm sektöründe konaklama işletmeleri özelinde kriz dönemlerinde uygulanan pazarlama, maliyet ve finansman odaklı stratejileri Tablo 1'deki gibi gruplandırmak mümkündür.

Tablo 1. Krizle Mücadelede Konaklama İşletmelerinde Uygulanan Pazarlama, Maliyet ve Finansman Stratejileri

\begin{tabular}{|c|c|c|}
\hline Pazarlama Odaklı Stratejiler & Maliyet Odaklı Stratejiler & Finansman Odaklı Stratejiler \\
\hline 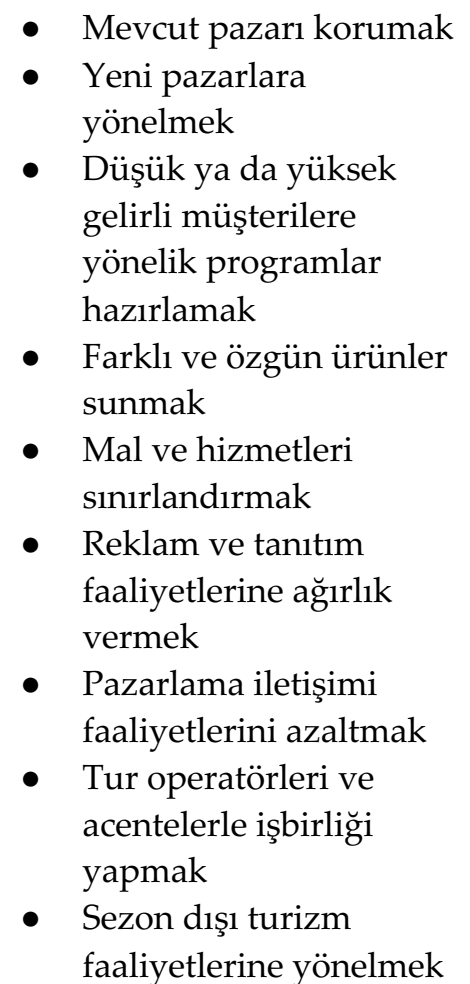 & $\begin{array}{ll}\text { - } & \text { Personel sayısını } \\
\text { - } & \text { Peraltmak } \\
\text { - } & \text { düşürmel ücretlerini } \\
\text { - } & \text { Verimliliği artırıcı } \\
\text { tedbirler alarak } \\
\text { maliyetleri düşürmek } \\
\text { - Yiyecek - içecek } \\
\text { maliyetlerini azaltmaya } \\
\text { yönelik tedbirler almak } \\
\text { İşletme malzemesi stok } \\
\text { seviyesini düşürmek } \\
\text { - } \quad \begin{array}{l}\text { Dolaylı işgücü } \\
\text { maliyetlerinde }\end{array} \\
\text { (ikramiye, servis, } \\
\text { yemek, vardiya vb.) } \\
\text { kesintiye gitmek } \\
\text { - Genel olarak tüm } \\
\text { maliyetleri azaltmak } \\
\text { - Yapımı devam eden } \\
\text { fiziksel tesislere ilişkin }\end{array}$ & $\begin{array}{ll}\text { - } & \text { Kredi kullanım miktarını } \\
\text { artırmak } \\
\text { - } & \text { Likit kalmak } \\
\text { - } & \text { Borçların vadelerini } \\
& \text { uzatmaya yönelik } \\
\text { anlaşmalar yapmak } \\
\text { - } & \text { Reklam, tanıtım ve } \\
\text { iletişim bütçelerinde } & \text { kesintiye gitmek } \\
\text { - } & \text { Kısa vadeli fonlardan } \\
\text { kaçınmak } \\
\text { - Alacak devir hızını } \\
\text { artırmak } \\
\text { - Müşterilere kredili } \\
\text { satışların vadelerini } \\
\text { uzatmak } \\
\text { - Tedarikçilerden kredili } \\
\text { mal alımlarında vade } \\
\text { uzatılmasını talep etmek } \\
\text { Kisa vadeli banka } \\
\text { kredilerine başvurmak }\end{array}$ \\
\hline
\end{tabular}




\begin{tabular}{|c|c|c|}
\hline 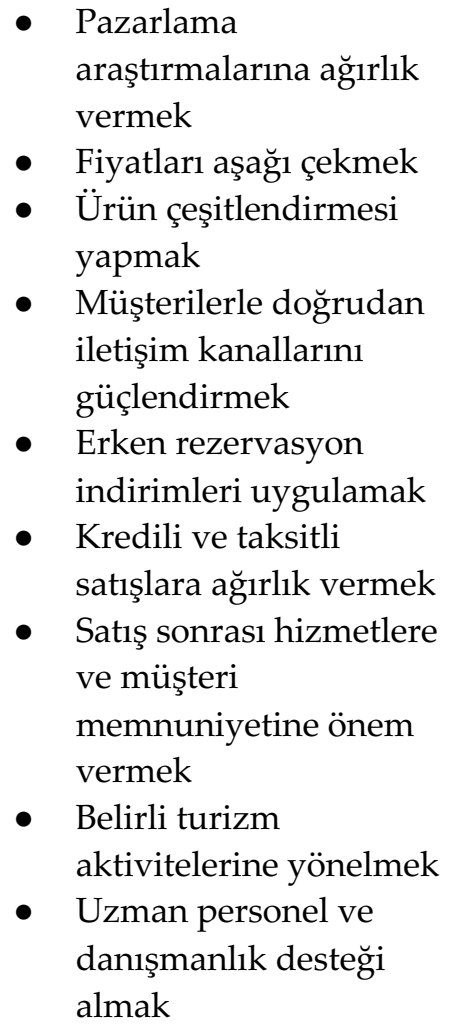 & $\begin{array}{ll} & \text { çalışmaları durdurmak } \\
\text { - } & \text { Dış hizmet alımlarına } \\
\text { - } & \text { Yennelmek yatırımları ve } \\
\text { projeleri ertelemek } \\
\text { - } & \text { Maliyet kontrolüne } \\
\text { ilişkin sürekli eğitim } \\
\text { programları } \\
\text { gerçekleştirmek } \\
\text { - Hizmet merkezlerinde } \\
\text { (restoran, bar, cafe vd.) } \\
\text { etkin maliyet kontrolleri } \\
\text { gerçekleştirmek } \\
\text { - Kâr marjı düşük ürün } \\
\text { ve hizmetlerin } \\
\text { sunumuna son vermek } \\
\text { - Sabit maliyetlere } \\
\text { yönelik maliyet tasarruf } \\
\text { stratejileri uygulamak } \\
\text { (varlıkları azaltmak vb.) } \\
\text { Bakım ve onarım } \\
\text { harcamalarını ertelemek }\end{array}$ & $\begin{array}{ll}\text { - } & \text { Uzun vadeli banka } \\
\text { - } & \text { Sredileri kullanmak } \\
& \text { öz kaynaklırı arımı yoluyla } \\
& \text { güçlendirmek } \\
\text { - } & \text { Nakit satışlarda indirim } \\
& \text { yapmak } \\
\text { - } & \text { Mevcut menkul kıymet } \\
& \text { yatırım araçlarını satarak } \\
\text { nakite çevirmek } \\
\text { - } \quad \text { Kâr dağıtımı yapmamak } \\
\text { - Kârlılı̆̆ düşük hizmet } \\
\text { birimlerinin bütçelerinde } \\
\text { kesintiye gitmek }\end{array}$ \\
\hline
\end{tabular}

Yazındaki araştırmalara ve uygulamalara bakıldığında, krizlere karşı uygulanan stratejiler arasında pazarlama iletişimi faaliyetlerinin kapsamının değiştirilmesi, mal ve hizmetlerin kapsamına yönelik düzenlemeler yapılması, vergi indirimleri, kredi destekleri, seyahat acenteleri ile işbirlikleri oluşturması, fiyat indirimleri, taksitli satışlar, personel maliyetlerinin azaltılması, genel giderlerin kısılması, uzun vadeli borçlanma, borç yapılandırması gibi uygulamaların öne çıktığı ifade edilebilir.

\section{Araştırma Soruları}

Yukarıda sunulan kavramsal çerçeve kapsamında ve çalışmanın amacı doğrultusunda oluşturulan araştırma soruları şunlardır:

A.S.1: Krizle başedebilmek için işletmelerin pazarlama alanında yapması gereken faaliyetler konusunda karar vericiler ne düşünmektedir?

A.S.2: Krizle başedebilmek için işletmelerin maliyet azaltııı faaliyetleri konusunda karar vericiler ne düşünmektedir?

A.S.3: Krizle başedebilmek için işletmelerin finansman alanında yapması gereken faaliyetler konusunda karar vericiler ne düşünmektedir?

A.S.4: Krizle başedebilmek için devletin yapması gereken faaliyetler konusunda karar vericiler ne düşünmektedir? 


\section{VERİ TOPLAMA SÜRECİ ve ANALİZ}

Çalışma kapsamında otel işletmelerindeki karar vericilerin bir kriz süresince neler yapılması gerektiği konusundaki görüşleri bütüncül şekilde araştırıldığından nitel bir araştırma tasarımı uygun görülmüştür. Böylece katılımcıların deneyimlerinden beslenen değerlendirmelerinin ve sahip oldukları düşüncelerin derinlemesine incelenmesi hedeflenmiştir. Krizin başında ve sonunda aynı katılımcılarla iki ayrı görüşme yapılarak iki aşamalı bir veri toplama süreci kurgulanmıştır. Bu sayede kriz süresince edinilen deneyimlerin de katılımcıların görüşlerini nasıl şekillendirdiği irdelenmiş, bu deneyim sonucunda katılımcıların krizle mücadele yöntemleri konusundaki düşüncelerinin ne olduğu anlaşılmaya çalışılmıştır. Araştırma problemini yanıtlamak üzere nitel araştırma yöntemlerinden derinlemesine görüşme yöntemi kullanılmıştır. Birinci görüşmeler krizin henüz hissedilmeye başlandığı 2016 yılı Nisan ayında, ikinci görüşmeler ise yaklaşık 2 yıl sonra krizin etkilerinin azaldığı 2018 yılı Mayıs ayında yapılmıştır. Bu bağlamda Türkiye'nin Muğla ilinde faaliyet gösteren 4 küçük ölçekli, 3 büyük ölçekli otel işletmesinin ortakları veya üst düzey yöneticileri ile görüşülmüştür. Farklı ölçeklerde işletmelerde görev yapan katılımcılar ile görüşülerek, ölçekten kaynaklanan algı farklılıkları bertaraf edilmeye çalışılmıştır.

Görüşmelerde yarı-yapılandırılmış görüşme formları kullanılmış ve görüşmelerin ses kayıtları alınmıştır. Görüşme formları yazın taraması sonucunda oluşturulmuştur ve demografik özelliklere yönelik sorular ile başlamaktadır. Formun ikinci kısmında, belirlenmiş olan temalar konusunda katılımcıların görüş ve değerlendirmelerini irdeleyen çeşitli sorular yer almaktadır. Görüşmelere iki araştırmacı katılmış, biri düzenleyici rolü üstlenirken diğeri görüşmeyi gözlemlemiş ve çevresel etmenleri kontrol etmiştir. Elde edilen ses kayıtları öncelikle metin haline dönüştürülmüş ve betimleyici analiz kullanılarak bulgular elde edilmiştir.

Betimleyici analiz kapsamında öncelikle veriler sistematik bir şekilde incelenmiş ve düzenlenmiştir. Daha sonra kavramsal çerçeve kapsamında belirlenmiş ve görüşmeler esnasında şekillendirilmiş olan temaların altlarına işlenmiştir. Çalışmanın amacına hizmet ettiği düşünülen önemli kısımlara doğrudan alıntı şeklinde yer verilmiştir. Son olarak veriler sade ve açık bir şekilde tanımlanarak açıklanmış ve bulgular irdelenerek yorumlanmıştır. Araştırmada görev alan iki araştırmacı veri toplama ve analiz sürecini paylaşmıştır. Şöyle ki, analiz sürecinde bir görüşmede düzenleyici rolü üstlenmeyen araştırmacı analizi yürütmüş, düzenleyici olan araştırmacı ise gerekli gördügü noktalarda görüş bildirmiştir. Bu şekilde araştırmanın güvenilirliğinin artırılması hedeflenmiştir (Yıldırım ve Şimşek, 2013).

\section{BULGULAR}

Alan araştırması kapsamında katılımcılara kriz döneminde alınacak tedbirler konusunda farklı paydaşlara ilişkin çeşitli temalar altında sorular sorulmuştur. Göz önünde bulundurulan paydaşlar işletmenin kendisi ve devlet ile sınırlandırılmıştır. Bu bağlamda devletten beklenen faaliyetler tek bir tema olarak değerlendirilirken işletme tarafından alınacak tedbirler ise pazarlama, maliyet ve finansman başlıkları altında sınıflandırılmıştır. Dolayısıyla veriler toplamda dört tema altında toplanmışlardır. Yazın taraması sonucunda kararlaştırılan bu temaların altında yer alan verilerin araştırma sorularına yanıt verdikleri varsayılmaktadır. Metin haline dönüştürülen veriler düzenlendikten sonra ulaşılan çıkarımlar ve önemli kısımlar seçilerek doğrudan alıntılar şeklinde ilgili temanın altına işlenmiştir. 


\section{Safha 1}

Alan araştırmasının ilk safhası krizin hissedilmeye başlandığı dönemde, Nisan 2016'da gerçekleştirilmiştir. Elde edilen bilgiler dört tema altında toplanmıştır.

\section{İşletmelerin Maliyet Azaltıcı Eylemleri}

İşletmelerin ölçeklerinden bağımsız olmak üzere kriz dönemlerinde öncelikle maliyet azaltıcı tedbirlere yöneldikleri tespit edilmiştir. Bu yöntemler içinde en çok sözü geçen personel giderlerinin azaltılmasıdır. Katılımcılar personel sayısını azaltarak ya da çalışanlara ücret artışı yapmayarak işletme giderlerinin azaltılabileceğini belirtmişlerdir. Çalışanların ücret artışından vazgeçmeleri gerekliliği, işletmeye duyulan bağlllı̆̆ın bir göstergesi olarak görülmektedir. Gerçekleştirilen görüşmelerde, büyük ölçekli (BÖ) ve küçük ölçekli (KÖ) otel işletmesi yöneticilerinin konuya ilişkin görüşlerinden genel bakış açısını temsil eden ifadeler aşağıdaki gibidir.

BÖ: “Otelimiz genelde masrafları azaltmaya çalışır, ancak kriz çıkınca bu konu daha da önemli oluyor. Personel giderlerimizi, genel işletme giderlerini, yani akla gelebilecek her türlü kalemi azaltmaya ve maliyetleri düşürmeye çalısııoruz. Hepimizin fedakarlı yapması lazım, gerekirse maaş artışından vazgeçmek gerekebilir"

KÖ: “...Krizde daha az elemanla çalışıyoruz tabi. Aslında müşteri bir kat azalıyor ama bizim çalışanı iki kat azaltmamız gerekiyor. Yoksa nasıl başedelim, bir sürü masraf var... sıkıntılı dönemlerde herkes taşın altına elini koymal, biz bir aileyiz sonuçta..."

\section{İşletmelerin Pazarlama Programı Kapsamındaki Eylemleri}

Katılımclara kriz döneminde uygulanacak pazarlama faaliyetleri sorulduğunda çoğunlukla pazarlama iletişimi odaklı faaliyetlerden bahsetmişlerdir. Bu durum küçük ölçekli işletmelerdeki katılımcılarda daha belirgin olarak görülmektedir. Pazarlama iletişimi bütçelerinde mecburen kesintiye gidilmesi gerektiğinden bahsedilmiştir. Mevcut müşterilerin korunmasının önemi vurgulanmış, ancak bunu yapmak için bir ön analiz yapmadıkları veya sistematik bir planlarının olmadığı tespit edilmiştir.

BÖ: "Öncelike mevcut müşterileri korumak lazım. Hizmetimizi bilen insanlar tekrar ikna etmek daha kolay oluyor."

BÖ: “Alacağımız ilk önlem maliyeti yüksek reklamları azaltmak oluyor. Şimdi tabi buna satış pazarlamacılar karşı çıkıyor ama o reklamın bize dönüşünden memnun değiliz ki. Dergiye reklam veriyoruz mesela ama müşterilere sorunca hiç kimsenin onu görmediğini anliyoruz"

KÖ: “...Yılbaşında eşantiyon dağıtmadık bu yıl, gelecek sene de zor gibi, sonra da duruma bakacağız artık..."

\section{İşletmelerin Finansman Odaklı Eylemleri}

Görüşme yapılan işletmelerde, krize karşı uygulanan veya uygulanması düşünülen finansman stratejilerinin başında işletmeden kısa vadede nakit çıkışını azaltmaya yönelik eylemlerin öne çıktığı görülmüştür. Katılımcılar öncelikle, kredili alımlarda vade uzatmaya ve kredi borçlarında yapılandırmaya gitmeye yönelik çabalar içinde olduklarını ifade etmişlerdir. 
BÖ: Bizde tüketim malları en büyük stok kalemlerimizden bir tanesi. Özellikle yüksek sezon öncesinde tedarikçilerden yüklü miktarlarda alımlar yapıyoruz. Tabi çoğu kredili bu alımların. Normal koşullarda tahsilat ve ödeme süreçlerimiz belirli bir dengededir. Pek sorun yaşamayız. Fakat son dönemde yaşanan olaylar nedeniyle, ödemelerimizin aksama ihtimali vardır. Bu yüzden, özellikle yakın ilişki içinde olduğumuz tedarikçilerimize bize satışlarda daha uzun vadeler tanıması yönünde taleplerimizi ilettik...

KÖ: Sezona girdiğimiz şu günlerde Rusya ile ülkemiz arasında yaşanan gerilim açıkcası bizi de olumsuz etkiledi. Bankadan daha önce almış olduğumuz kredilerin geri ödemelerinde zorluklar yaşama ihtimalimiz çok yüksek. Bu yüzden borç yapılandırması konusunda bankayla görüşüyoruz. Bu konuda devletin de bize destek vermesini bekliyoruz.

Yapılan görüşmelerde katılımcıların finansal çözümlere yönelik düşünceleri genel olarak bu çerçevede şekillenmiştir. Zira, büyük ölçekli işletmeler yüksek miktarlarda satın alımlar yapmaları nedeniyle tedarikçilere yönelik iskonto, uzun vade gibi taleplerde bulunabilmekte iken, küçük ölçekli işletmeler için bu durum daha zordur. Dolayısıyla, küu̧ük işletmeler daha ziyade finans kuruluşlarından temin etmiş oldukları kredilere ilişkin borçları yapılandırma yoluna gitmektedir.

\section{Devletten Beklenen Faaliyetler}

Katılımcılar krizler ile başetme sürecinde paydaşlar içinde en çok devleti sorumlu görmektedir. Devletin sorumlulukları arasında görülen faaliyetlerin başında vergi indirimleri gelmektedir. Bu başlık altında yiyecek-içeceklerdeki KDV oranları ve personel ücretleri için uygulanan vergi oranların azaltılması yer almaktadır. Diğer yandan otel işletmelerine düşük faizli kredi desteği sağlanması talep edilmektedir. Devlete atfedilen bir diğer sorumluluk yaşanan siyasi gerilimler ve terör olaylarından ötürü bozulan ülke imajının çeşitli faaliyetlerle düzeltilmesidir. $\mathrm{Bu}$ kapsamda özellikle belirli turizm bölgelerinin güvenli olduğunun vurgulanması istenmektedir.

BÖ: Devletin bize destek olması lazım. Çok vergi veriyoruz, yiyecek içeceklerdeki KDV yüksek, daha düşük olmal. En kötü bu kriz zamanında vergide indirim olmalı... Personel maliyetimiz çok yüksek, elemana verdiğimiz kadar devlete de veriyoruz. Sonra deniyor ki hizmet kaliteni yükselt, nasıl olacak bu iş? Yetişmiş elemanı elimizde tutalım ki iyi hizmet verelim değil mi?

BÖ: Ülkenin tanıtımı iyi yapılmalı, imajımız bozulmamalı... Turiste her türlü kolaylı̆̆ın sağlanması lazım, kapıda beklemeyecek gelen insanlar. Bizim geleneklerimizde misafire iyi davranilır, bekletilmez, güzel ağırlanır

KÖ: Tarımla uğraşanlara sürekli uygun kredi veriyor devlet, biz yabancı para kazandırıyoruz memlekete, bizim de desteklenmemiz lazım. Mesela kendimizi geliştireceğiz, diyecekler ki al kardeşim faizsiz para, kullan bunu döviz gelsin. Harca ki daha iyi ol, daha çok turist çek...

\section{Safha 2}

Araştırmanın ikinci safhasında krizin etkilerinin azalmaya başladığı dönemde (Mayıs 2018) yapılan görüşmeler ile veri toplanmıştır. Elde edilen bilgiler ilk safhadaki aynı dört tema altında toplanmiştır.

\section{İşletmelerin Maliyet Azaltıcı Eylemleri}

Araştırma kapsamında görüşülen işletmelerin ağırlıklı olarak mevsimlik işçi çalıştırarak personel giderlerini azaltma stratejisini tercih etme eğiliminde oldukları görülmüştür. İşletmeler, istihdam politikalarının daha esnek bir yapıya kavuşturulabileceğini vurgulamıştır. Sürekli olarak faaliyet 
gösteren işletmelerde belirli sayılarda personel 12 ay boyunca istihdam edilirken, yüksek sezonda ilave geçici eleman alındığı belirtilmiştir. Bu politikanın hizmet kalitesini düşüreceği ve normal dönemlerde uygulanmayabildiği, ancak kriz dönemlerinde zorunlu kalındığı anlaşılmaktadır.

BÖ: Yıl boyunca çalışan personelin sayısını azaltıp mevsimlik eleman almak epey işe yarayan birşey, bizim açımızdan karlı. Yüksek sezon dışında azalan misafir sayılarımızla baş etmemiz kolaylaşıyor böyle...

BÖ: Rusya ile yaşadığımız sıkıntıdan dolayı geçtĭ̆imiz sezon biraz zorlandık açıkcası. İster istemez çalı̧anların maaşlarına yapacağımı zammı ertelemek durumunda kaldık.

KÖ: Mecburen daha az elemanla daha çok iş yaptığımız dönemler oluyor. Geçen sezon elemanlarımızın bazılarına ücretsiz izin vermek durumunda kaldık...

\section{İşletmelerin Pazarlama Programı Kapsamındaki Eylemleri}

Pazarlama iletişimine ayrılan bütçenin azaltılmasının mevcut müşteriyi korumak ve potansiyel müşterilerin kazandırılmasında sorun teşkil ettiği belirtilmektedir. Kriz dönemlerinde rekabetin daha da artması nedeniyle iletişimi kısmak yerine fiyatların azaltılmasının işe yaradığı ifade edilmiştir. Ancak düşük fiyat politikasının uzun vadede sürdürülemez olduğu, fiyatları tekrar artırmak gerektiğinde ise müşterilerin düşük fiyat deneyimlerinden dolayı olumsuz tepkiler gösterdiklerinden veya rakiplere yöneldiklerinden yakınılmaktadır. Diğer yandan müşterilere sunulan mal ve hizmetlerde kısıntıya gidilmesinin de toplam talebi ve müşteri memnuniyetini olumsuz anlamda etkilediği görülmüştür. Son olarak farklı ülkelerden de turistlerin çekilmesi gerektiği, tek bir pazar odaklı çalışıldığında bu tür krizlerden daha fazla etkilenildiği belirtilmiştir.

BÖ: Tanıtım harcamalarımızı kısalım derken kaş yaparken göz çıkarıyoruz. Zaten piyasa kötü, müşterinin gözü önünde olmazsan adam başkasına gidiyor, seçenek o kadar fazla ki... belirli dönemlerde özellikle yüksek sezon dışındaki bazı tarihlerde fiyat indirimlerine geri dönüş iyi oluyor. Ama bu sefer de misafirler o fiyata alışıyor, normal fiyata döndü̆̈̈̈mizde kazık atıyoruz sanıyor.

KÖ: Başka ülkelerde de rakip çok, neresi uygun gelir hoşuna giderse oraya gidiyor herkes... En etkili yöntem düşük fiyat, bizim hitap ettiğimiz kesim belli. Tabi denizine, ulaşımına bakıyorlar ama en çok dikkkat edilen şey fiyat. Fiyatı uygun tutunca talep artıyor. Zor zamanlarda mecburen böyle yapıyoruz.

\section{İşletmelerin Finansman Odaklı Eylemleri}

İşletmeler kriz döneminde azalan satışlarını artırabilmek ve yeterli nakit girişi sağlayabilmek için yerli turistlere yönelik kampanyaların yanısıra müşterilere nakit satışlarda indirim yapma, taksitli satışlarda vade uzatma gibi uygulamalar gerçekleştirdiklerini belirtmişlerdir. Diğer taraftan, işletmeler tedarikçilerden kredili alımlarda vade uzatma talepleri ile finans kuruluşlarından kısa vadeli borçlarının uzun vadeye dönüştürülmesi yönündeki taleplerinin yeterince karşılanmadığını ifade etmişlerdir.

BÖ: Rus hükümetinin vatandaşlarına Türkiye'ye gitmemeleri yönünde uyguladığı politikalar bu sezon satışlarımızı çok daralttı. Açıkcası biz turizmciler açısından çok bunaltıcı bir sezondu. Taksitli satış, peşin ödemede indirimler gibi yöntemlerle nakit ihtiyacımızı gidermeye çalıştı. Sonuçta vadesi gelen borçlarımızı bir şekilde ödemek durumundayız ve bunun içinde satış yapmamız gerek...

KÖ: Bizim sektörümüz için huzur ve güven ortamı olmazsa olmazlardan. Son günlerde yaşanan talihsiz olaylar sanırım en çok bizi etkiledi. Ülkemiz yabancı turistlerin yoğun ilgi gösterdiği bir yer. Bunun sonucu 
olarak bizim de müşteri potansiyelimizin büyük bir bölümünü yabancllar oluşturuyor. Durum böyle olunca, yaşanan bu tür huzursuzluklar bizi çok etkiliyor. Bu sezon yaşadığımız sıkıntıları yenmek için yerli turistleri çekmeye yönelik kampanyalar uygulamaya çalıştı...

\section{Devletten Beklenen Faaliyetler}

Kriz süresince devletten beklenen faaliyetlerin yeterince gerçekleştirilmediğinden yakınılmıştır. Beklenen vergi indirimleri yapılmadığı için maliyetlerde azalma gerçekleşmemiştir. Devletten beklenen pazarlama faaliyetleri ise tam olarak memnuniyet yaratmamıştır. Potansiyel pazarlara yönelme konusunda devletin daha fazla çaba ve kaynak harcaması gerektiği düşünülmektedir.

BK: Zor dönemlerde ülke tanıtımına daha çok önem verilmesini bekliyoruz. Doğru yöntemler ile Türkiye'nin potansiyel misafirlerine ulaşılması gerekiyor. Ama yaşanan tatsız hadiselerden sonra yapılması gerekenleri pek göremedik. Başka ülkelere de bakıyoruz, bizde de ilave bir tanıtım kampanyası bekliyorduk ama pek olmadi...

KK: Yaşanan kötü olaylar ile ülkenin imajı bozuluyor. Kim ister ki tatilini tehlike altında yapsın. Buraya gelenler anlıyor buraların çok güvenli olduğunu ama ya gelmeyenler? Devletimizin buraların çok güvenli olduğunu herkese anlatması lazım. Buna bizim gücümüz yetmez ama devletin imkanı bol, heryere reklam verebilir...

\section{SONUÇ ve TARTIŞMA}

Çalı̧̧mada Muğla ilinde faaliyet gösteren çeşitli ölçeklerdeki otel işletmelerindeki karar vericilerin bir krizin başında ve sonunda krizi bertaraf etmek için yapılması gerekenlere ilişkin değerlendirmeleri irdelenmiştir. Yazında kriz dönemlerinde turizm sektöründe yapılması gerekenleri inceleyen çalışmalara rastlanmaktadır. Ancak, Türkiye'deki otel işletmeciliği alanında karar vericilerin düşüncelerini derinlemesine irdelemenin, durumsal etmenlerin etkisini görmeye katkı sağladığı düşünülmektedir. Elde edilen bulgular ile karar vericilere göre krizle mücadele sürecinde temelde sorumluluğun hangi paydaşta olduğu, pazarlama, finansman ve maliyet odaklı konularda ne tür eylemler yapılması gerektiği açıklığa kavuşturulmuştur. İşletme biliminin bu tür durumlarda önerdiği eylemlere kavramsal çerçevede yer verilmiştir. Bunun yanısıra çalışma, işletmelerin krizle baş etme stratejilerini belirleme sürecinde Türkiye'deki karar vericilerin düşüncelerinin bilimsel öneriler ile ne kadar örtüştüğü veya çeliştiği konusunda iş hayatına katkıda bulunmayı da hedeflemiştir. Diğer yandan verilerin iki safhada toplanması sayesinde, katılımcıların krizi deneyimledikten sonra görüşlerinin değişip değişmediği anlaşılmaya çalışılmıştır. Zira yazında kriz esnasındaki ve kriz sonrasındaki durumu karşılaştırmalı olarak birlikte ele alan az sayıda çalışma bulunmakta (Ritchie ve Jiang, 2019), ve bu durum krize karşı alınması gereken önlemlerin nesnel bir şekilde ortaya çıarılmasını zorlaştırmaktadır.

Katılımcılar krizin yeni hissedildiği dönemde, yapılması gerekenler hususunda devletin sorumlulukları üzerine yoğunlaşmışlardır. Devletin ülke tanıtımına ekstra kaynak ayırmanın yanında vergi indirimleri ve borç yapılandırma gibi çözümler üretmesi gerektiğini savunmuşlardır. Beklenen çözümler arasında; turistlere vize kolaylığı sağlanması, yiyecek içecek sektöründe uygulanan katma değer vergisi (KDV) oranlarının düşürülmesi, otel işletmelerinin yenilenmesi için proje desteği verilmesi, ülke tanıtımı için ayrılmış bütçe kaleminde artış yapılması, küçük ve orta ölçekli otel işletmelerine kredi sübvansiyonu, düşük faizli krediler verilmesi, banka garantisi oranının artırılması, kredi kartı ile satışlarda taksit olanaklarının artırılması için bankalara teşvik sağlanması gibi uygulamalar yer almaktadır. 
Bunun yanı sıra işletme bünyesinde ise personel sayısının azaltılması, personel ücretlerinin düşürülmesi, pazarlama iletişimi bütçesinin azaltılması, uygulanan fiyatlarda indirime gidilmesi gibi yöntemler üzerine odaklandıkları görülmüştür. İşletmeler ağırlıklı olarak maliyet azaltma stratejilerine odaklanmakla birlikte bir takım finansman odaklı çabalar da sergilemektedir. Uygulanmaya çalışılan en yaygın finansman politikası, kredili alımlarda vade uzatma ve kredi borçlarında yapılandırmaya gitme şeklinde karşımıza çıkmaktadır. Kriz dönemlerinde alacakların tahsilatında ve nakit girişinde yaşanabilen sıkıntılar borç ödemelerinin aksamasına ve işletmelerin iflasına kadar gidebilecek süreçlerin oluşmasına neden olabildiğinden işletmelerin bu yaklaşımı gayet makul görünmektedir. Pazarlama alanında yapılması gereken faaliyetler konusunda katılımclar ağırlıklı olarak pazarlama iletişimi üzerinde durmuştur. Ancak hem pazarlama iletişiminde hem de diğer paydaşlar ile bilgi alışverişinde oldukça önemli bir rol oynayan sosyal medya araçlarının bu çalışmada ele alınan kriz esnasında katılımcılar tarafından kullanılmadığı tespit edilmiştir. Oysa Antony ve Jacob'e (2019) göre turizm sektörünün karşılaştı̆̆ krizlerde sosyal medya platformları krizle mücadalede önemli katkılarda bulunmaktadır. Dolayısıyla işletmelerin pazarlama iletişiminde sosyal medya kullanım becerilerini geliştirmelerin faydalı olacağı düşünülmektedir. Devletin, sektörel örgütlerin veya diğer yetkili mercilerin bu konuda çalışmalar yapması faydalı olacaktır.

Krizin etkilerinin azalmaya başladığı dönemde gerçekleştirilen çalışmanın ikinci safhasında ise katılımcılar devlet uygulamalarının çözüm üretmekte beklenen düzeyde gerçekleşmediğini düşünmektedir. Özellikle sektörde KDV indirimine gidilmemesi, ülke tanıtımı için ayrılan bütçede yeterli düzeyde iyileştirme yapılmaması gibi durumların işletmelerini yaşanan kriz karşısında daha da zayıflattığını belirtmişlerdir. Ayrıca kredi faiz oranlarındaki artış nedeniyle ihtiyaç duyulan finansmanın temininde sıkıntılar yaşadıklarını ifade etmişlerdir.

Personel harcamalarındaki indirimin işe yaradığını savunan yöneticiler çoğunlukta iken, pazarlama iletişimi faaliyetlerini azaltmanın düşen talebi daha da kötü yönde etkilediği sonucuna ulaşılmıştır. Diğer taraftan katılımcılar, fiyatlarda indirime gidilmesinin kısa vadede müşteri talebinde olumlu etkileri olduğunu düşünürken, sunulan mal ve hizmetlerde sınırlamaya gidilmesinin müşteri memnuniyetini olumsuz yönde etkilediğini ifade etmişlerdir. Ayrıca katılımcıların çoğu risk dağıtımı için farklı ülkelerle çalışılması gerekliliğini işaret etmişlerdir. Bu bulgular, del Mar Alonso-Almeida ve Bremser (2013) tarafından ortaya konulan ve pazarlama bütçesinde, sunulan mal ve hizmetlerde sınırlamaya gidilmesi gibi maliyet azaltmaya yönelik uygulamaların işletmelerin performansını olumsuz etkilediği yönündeki sonuçlarla örtüşmektedir.

İki safhada elde edilen veriler karşılaştıııldığında, pazarlama odaklı eylemler açısından işletmelerin krizin başında en çok pazarlama iletişimi bütçesinin azaltılması ve fiyat ayarlamaları üzerinde durdukları görülmüştür. Kriz deneyiminden sonra ise pazarlama iletişiminin öneminin daha iyi kavrandığı söylenebilir. Ayrıca ikinci safhada mevcut müşterilerin elde tutulmasının yanında yeni müşterilerin kazanılması ya da yeni pazarlara açılınması gerektiğinden bahsedilmiştir. Bu noktada, seyahat acentalarının, otel işletmelerinin uyguladıkları pazarlama programında sahip oldukları önemli işlevler nedeniyle, krizle mücadelede sürece daha etkin biçimde dâhil edilmesi yönünde adımlar atılmasının faydalı olacağı söylenebilir. Nitekim, Emir (2010), Muğla ve İstanbul illerindeki otel işletmelerinin pazarlama programında seyahat acentalarının rolünü araştırdığı çalışmasında, otel işletmelerinin yeni pazarlara açılma, müşteri memnuniyeti yaratma ve yeni müşterilere ulaşma gibi faaliyetlerinin başarısında, seyahat acentalarının etkinliğinin önemli bir unsur olduğunu ortaya koymuştur. Dolayısıyla gerek krizlere karşı hazırlıklı olmak gerekse krizlerin yol açacağı olumsuzlukların en aza indirgenebilmesi açısından otel işletmeleri ile seyahat acentaları arasındaki ilişkilerin geliştirilmesi, kriz dönemlerinde seyahat acentalarına devlet destekleri sunulması ve kriz 
yönetim süreçlerine aktif katılımlarının sağlanmasının olası kayıpların azaltılmasına yardımcı olacağı düşünülmektedir. Genel olarak bakıldığında katılımcıların pazarlamanın kavramsal kapsamına hâkim olmadığı, yani modern pazarlamanın nelerden oluştuğunun genelde bilinmediği, pazarlamanın sadece satış geliştirme çabaları ve iletişim yöntemleri ile örtüştürüldüğü tespit edilmiştir. Bu doğrultuda, yöneticilere yönelik eğitimler düzenlenmesi, devlet tarafından sektördeki profesyonellerin de yer aldığı afet ve kriz yönetim komiteleri oluşturulması gibi uygulamaların sistematik olarak hayata geçirilmesi ve bu uygulamaların sürekliliğinin sağlanması önem arz etmektedir.

Katılımcıların değerlendirmeleri genel olarak incelendiğinde, kriz süresince çoğunlukla kısa vadeli önlemler üzerine odaklandıkları tespit edilmiştir. Ancak yazında krizle mücadelenin uzun vadeli bir bakış açısı ile yapılması gerektiği (Stafford vd., 2002) belirtilmektedir. Ayrıca, işletmelerin krizle mücadelede maliyet azaltıcı eylemlere finansman odaklı eylemlerden daha fazla önem verdikleri görülmüştür. Bu tespit, Met ve Akkaşoğlu'nun (2015) Antalya konaklama işletmelerinin 1997-2008 döneminde yaşanan krizlere karşı uyguladığı stratejileri araştırdığı çalışmada elde edilen sonuçlarla örtüşmektedir. Diğer yandan karar vericilerin yapılması gerekenler konusunda temel sorumluluğun devlette olduğunu düşündükleri söylenebilir. Bu durum, yazındaki çalışmalarda (Bahar, Kaya ve Keklik, 2011) birçok ülkede devletin mücadelede düzenleyici ya da uygulayıcı olarak sorumluluk üstlendiği durumlar ile örtüşmektedir. Ancak ilgili yazında devletin oynadığı rolün işletmelere göre ne düzeyde ve yoğunlukta olması gerektiğine değinilmemektedir. Bir başka deyişle, krizle mücadele sürecinde devletin ne düzeyde bir sorumluluk üstlenmesi gerektiği konusunda farklı ülkelere ilişkin veriler bulunmamaktadır. Oysa söz konusu düzeye ilişkin beklentinin ülkeden ülkeye farklılık gösterebileceği düşünülmektedir. Bu noktada krizin gerçekleşme nedeninin ve yapısının, kültürel ve çevresel etmenlerin, devletin kriz dönemlerindeki sorumluluk düzeyini özellikle otel işletmelerinin beklentileri açısından nasıl etkilediğine ilişkin gelecekte yapılacak çalışmalar yazına katkı sağlayabilir.

Oteller konaklama endüstrisinin önemli aktörleri olmalarına rağmen bu endüstrinin tamamını temsil etmemektedir. Bu nedenle elde edilen çlkarımlar diğer konaklama tesisleri için genellemek mümkün görünmemektedir. Son dönemlerde Airbnb gibi paylaşım ekonomisi örneklerinin konaklama endüstrisindeki önemi artmaktadır (bknz. Altinay ve Taheri, 2019; Mondal ve Samaddar, 2020). Bu tür farklı konaklama türlerinin de krizle mücadelede izleyecekleri yolları inceleyen çalışmalar kavramsal açıdan katkı sağlayabilir ve karar vericilere yardımcı olabilir.

Çalışmada analiz edilen veriler Muğla ilinde faaliyet gösteren ve ulaşılabilen işletmelerden toplanmıştır. Araştırma keşifsel yapıda olduğu ve nitel veri kullanıldığı için genelleme amacı güdülmemiştir. Ancak bunun yanında ülkenin farklı bölgelerindeki otel işletmelerinde, değişen koşullardan ötürü bu çalışmada ulaşılamayan görüş ve değerlendirmeler olabilir. Bu nedenle ülkenin farklı bölge ve şehirlerindeki otellerde görev yapan katılımcıların yer aldığı çalışmalar yapılması önerilmektedir.

İşletmelerin faaliyetleri ile doğrudan ilgili yerel yönetim, sivil toplum örgütleri, diğer ticari işletmeler (esnaf, ulaşım işletmeleri vb.) gibi farklı paydaşlar bulunmaktadır. Ekonomik sistemin birer parçası olan bu paydaşlar kriz döneminde veya olağan koşullarda işletmeleri etkileyebilirler. Bu çalışmada ise işletme içi etmenlerin yanında işletme dışı etmenlerden sadece merkezi yönetime (devlet) odaklanılmıştır. İleride yapılacak çalışmalarda söz konusu paydaşların etkilerinin de göz önünde bulundurulmasının yazına katkı sağlayacağı düşünülmektedir. 


\section{KAYNAKÇA}

Altinay, L. and Taheri, B. (2019). Emerging themes and theories in the sharing economy: a critical note for hospitality and tourism. International Journal of Contemporary Hospitality Management, 31(1), 180-193.

Antony, J. K. and Jacob, J. M. (2019). Crisis management in the tourism industry-the role of social media platforms. Atna Journal of Tourism Studies, 14(1), 83-96.

Bahar, E., Kaya, F. and Keklik, F. (2011). Struggle strategies with crisis in accommodation sector. International Journal of Economic and Administrative Studies, 3(6), 83-99.

Booth, S. A. (1993). Crisis Management Strategy: Competition and change in modern enterprises. London and New York: Routledge.

Cushnahan, G. (2004). Crisis management in small-scale tourism. Journal of Travel $\mathcal{E}$ Tourism Marketing, 15(4), 323-338.

Dalgıç, A. ve Birdir, K. (2017). Konaklama işletmelerinin kriz yönetimi uygulamaları ve beklentileri: Beş yıldızlı oteller üzerinde bir araştırma. Mehmet Akif Ersoy Üniversitesi Sosyal Bilimler Dergisi, 9(20), 216-235.

Davras, G. M. ve Aktel, M. (2018). 2015-2016 krizinin Türkiye turizmine yansımaları. Süleyman Demirel Üniversitesi Vizyoner Dergisi, 9(21), 27-38.

del Mar Alonso-Almeida, M. and Bremser, K. (2013). Strategic responses of the Spanish hospitality sector to the financial crisis. International Journal of Hospitality Management, 32, 141-148.

Emir, O. (2010). Otel işletmelerinin pazarlanmasında seyahat acentalarının rolü: Otel işletmeleri tarafından bir değerlendirme. Ege Akademik Bakış, 10(4), 1245-1256.

Hwang, P. and Lichtenthal, J. D. (1999). Anatomy of organizational crises. ISBM Report 28-1999, Institute for the Study of Business Markets, The Pennsylvania State University.

Iivari, P. (2012). Business crisis and its management: Crisis management as a part of safety and security management in a tourism company. Rovaniemi University of Applied Sciences Publications, Publication series $\mathrm{C}$ no. 31 .

Israeli, A. A., Mohsin, A. and Kumar, B. (2011). Hospitality crisis management practices: The case of Indian luxury hotels. International Journal of Hospitality Management, 30(2), 367-374.

Kaya, D. S. (2017). Turizm Sektörü. İş Bankası İktisadi Araştırmalar Bölümü, https://ekonomi.isbank.com.tr/ContentManagement/Documents/sr201704_turizm.pdf (Erişim tarihi: 3 Haziran 2017).

Kash, T. J. and Darling, J. R. (1998). Crisis management: Prevention, diagnosis and intervention. Leadership \& Organization Development Journal, 19(4), 179-186.

Kim, S. S., Chun, H. and Lee, H. (2005). The effects of SARS on the Korean hotel industry and measures to overcome the crisis: A case study of six Korean five-star hotels. Asia Pacific Journal of Tourism Research, 10(4), 369-377.

Lerbinger, O. (1986). Managing corporate crises. Boston, MA: Barrington Press.

Lerbinger, O. (1997). The Crisis Manager: Facing Risk and Responsibility. New Jersey: Lawrence Erlbaum Associates, pp. 10-14. 
Met, Ö. ve Akkaşoğlu, S. (2015). Konaklama işletmelerinin krizlere karşı izledikleri finansal stratejileri ve krizlere karşı tutumlarını belirlemeye yönelik Antalya bölgesinde bir alan araştırması. Uluslararası Alanya İşletme Fakültesi Dergisi, 7(1), 23-32.

Meyers, G. C. and J. Holusha (1986). When it hits the fan: Managing the nine crises of business. Boston, MA: Houghton Mifflin Company.

Mondal, S. and Samaddar, K. (2020). Issues and challenges in implementing sharing economy in tourism: a triangulation study. Management of Environmental Quality: An International Journal, July.

Okumus, F., Altınay, M. and Araslı, H. (2005). The impact of Turkey's economic crisis of February 2001 on the tourism industry in Northern Cyprus. Tourism Management, 26(1), 95-104.

Pforr, C. (2009). Crisis Management in Tourism: A Review of the Emergent Literature. In Crisis Management in the Tourism Industry: Beating the Odds?, ed. C. Pforr and P. Hosie. Surrey: Ashgate, $37-52$.

Ritchie, B. W., Crotts, J. C., Zehrer, A. and Volsky, G. T. (2013). Understanding the effects of a tourism crisis: The impact of the BP oil spill on regional lodging demand. Journal of Travel Research, 53(1), 12-25.

Ritchie, B. W. and Jiang, Y. (2019). A review of research on tourism risk, crisis and disaster management: Launching the annals of tourism research curated collection on tourism risk, crisis and disaster management. Annals of Tourism Research, 79, 102812.

Sawalha, I. H. S., Jraisat, L. E. and Al-Qudah, K. A. M. (2013). Crisis and disaster management in Jordanian hotels: practices and cultural considerations. Disaster Prevention and Management: An International Journal, 22(3), 210-228.

Scott, N., Laws, E. and Prideaux, B. (2008). Tourism crises and marketing recovery strategies. Journal of Travel \& Tourism Marketing, 23(2-4), 1-13.

Seeger, M. W., Sellnow, T. L. and Ulmer, R. R. (2003). Communication and organizational crisis. Westport, CT: Greenwood Publishing Group.

Sigindi, T. (2018). Consumers, Businesses, and Governments During an Economic Crisis: A Marketing Perspective. In [(ed.) Leon, R.D.; Managerial Strategies for Business Sustainability During Turbulent Times], IGI Global: 208-222.

Smith, L. and Millar, D. (2002). Crisis management and communication: How to gain and maintain control (2nd ed.). San Francisco, CA: International Association of Business Communicators.

Sönmez, S., Apostolopoulos, Y. and Tarlow, P. (1999). Tourism in crisis: Managing the effects of terrorism. Journal of Travel Research, 38(1):13-18.

Stafford, G., Yu, L. and Armoo, A. K. (2002). Crisis management and recovery: How Washington, D.C., responded to terrorism. Cornell Hotel and Restaurant Administration Quarterly, October, 2740.

Yıldırım, A. ve Şimşek, H. (2013). Sosyal bilimlerde nitel araştırma yöntemleri, (9.baskı). Ankara: Seçkin Yayıncılık. 